\title{
A Rational Basis for System Biology in the Aging-Associated Diseases: Are Genes or Protein Modifications the Upstream Cause?
}

\author{
Halina Z Malina \\ Correspondence: halinamalina@yahoo.com \\ MalinaLab-Axanton, Tiefenaustr.110 CH-3004 Bern, Switzerland.
}

\begin{abstract}
A vast amount of research has been carried out to prepare system biology that could clarify the development of the aging-associated diseases, but a leading hypothesis is lacking. The data are prepared in primary cells, cell line cultures, knockout animals, chemical treatment, and chemical treatment of the knockout animals. Are genes or protein modifications responsible for the diseases? The upstream question needs a response before data can be accumulated to explain a mechanism of pathology. Data should be interactive in a system of biology. Proteins play an executive role in system biology, and small molecules regulate the network. In system biology, the interactions between proteins should be regulated according to a rule, but if a rule is different, the system biology is different. The data cannot be transferred from one system to another. The regulation of the protein network by the small molecules is impaired in transgenic cells. In systems biology, gene deletion or protein modification by the small molecules respectively disrupts or covalently modifies the signaling protein network of the Cam, and phosphatidylinoside -binding proteins. The systems biology, created by gene deletion and protein modification, are different. One cannot hope to recreate a system that leads to the diseases in aging based on an accumulation of data from different systems. Transgenic mice should be used only as a model of genetic disease, which leads to impairment of physiology in early infancy, but cannot be a model of drug development for the aging-associated diseases. In spite of their genetic differences, people are usually healthy in the first century of their life; the challenge is to understand the system biology that leads to the decline of health in aging. Keywords: diseases, aging, genetic, chemicals, system biology, protein modification, drug targeting
\end{abstract}

\section{Background}

The diseases associated with aging impose the highest burden on society. Recently, many studies suggested that system biology construction would describe a mechanism for these diseases. The huge accumulation of data is followed by computational analysis to build "the system." However, research on system biology should have a logic-based background. System biology should have the features of a mathematical system, which is a collection of interdependent components forming an integrated whole. System biology cannot be only a collection of data. The data in the system should be interactive. The data cannot be transferred from one system to another; the system cannot be prepared based on data collected by a shotgun approach. System biology should be built on the discovery of the rules managing the interactions of the parts belonging to the system. Therefore, we should first determine the upstream cause of diseases to establish a rational background for system biology. Currently, the system is built on non-interacting data with an expectation that the data accumulation will pave a new path to halting diseases. We cannot build a system by accumulating data from different systems. We cannot use data from transgenic cells and expect to derive system biology for the aging-associated diseases that, according to many data, hold the modification of proteins by small molecules as the upstream cause.

\section{Discussion}

The primary cells, cell lines, transgenic cells, and the proteins modified by the small molecules have different protein-protein interactions-they belong to different systems biology

The difference between primary cells and cell lines has been observed for the last 20 years. Significant differences were found between the ability of human umbilical vein endothelial cells (HUVEC) and cell lines to respond to cytokines. The greatest differences were the induction of VCAM-1 and E-selectin in response to TNF- $a$, and induction of MHC class II antigens in response to IFN- $\gamma$. Migration of peripheral blood mononuclear cells was significantly reduced through all cell lines compared to HUVEC, suggesting that there is a functional difference between cell lines with regard to interactions with lymphocytes. A study demonstrated significant differences in the ability of endothelial cell lines to respond to cytokines compared to primary HUVEC cultures; for example, cell line ECV304 compares extremely poorly with HUVEC [1]. Comparison of a cholangiocarcinoma cell line with primary cultures of non-neoplastic biliary epithelial cells showed differences in the growth control of human biliary epithelial cells by interleukin 6, hepatocyte growth factor, transforming growth factor $\beta 1$, and activin [2]. The distribution of protein in transgenic animals was different from that in wild-type (WT) mice. Transgenic animals expressed high levels of adenylyl

(C) 2012 Halina Z Malina licensee Herbert Publications Ltd. This is an Open Access article distributed under the terms of Creative Commons Attribution License (http://creativecommons.org/licenses/by/3.0). This permits unrestricted use, distribution, and reproduction in any medium, provided the original work is properly cited. 
cyclase upon treatment with isoproterenol in comparison with WT mice [3]. The resulting quantitative proteome of 4,063 proteins had an asymmetric distribution, with many proteins being down-regulated in the cell line. Bioinformatics analysis of the quantitative proteomic phenotypes revealed that Hepa-1-6 cells were deficient in mitochondria, reflecting rearrangement of metabolic pathways, drastically up-regulated cell cycle-associated functions, and largely shut-down drugmetabolizing enzymes characteristic of the liver [4]. TCR ${ }^{\text {YKIII.8 }}$ transgenic T cells exhibited an increase of IFN- $\gamma$ production. Their activity was detectable in response to $\mathrm{EBV}_{\mathrm{d}}$ incubated in the presence of $10^{-8} \mathrm{M}$ of peptide, while YKIII.8 did not demonstrate any activity at this concentration. Taken together, these data prove that the sensitivity of TCR-transgenic T cells is equal or superior to that of the original clones [5]. Most publications in the last 20 years were generated based on the transgenic mice model, elucidating the changes in protein expression in a transgenic mice model; for example, TIMP-3 is mediated via inhibition of EGFR expression/phosphorylation, and decreased JNK and SP-1 signaling in a transgenic mice model [6]. The results obtained in a transgenic animal are different than in wild type animal.

\section{Are the genetic models appropriate for study the aging} associated diseases?

Consideration of the genetic background of the agingassociated diseases led to the genesis of transgenic animal models for drug discovery, which are requested in current drug development processes approved by regulatory authorities around the world. Transgenic animals were created to study the aging-associated diseases such as Parkinson's disease (PD), cardiovascular diseases (CVD), or Alzheimer's disease. Many expensive studies were performed to study the changes of protein expression in transgenic animal models and to study drug efficacy in the models. However, these studies did not lead to explanations of the diseases' etiology and did not prevent or stop such diseases. Current drugs do not target the cause of the diseases, but their symptoms. The small molecules for the aging-associated diseases are chosen by high-throughput screening tested on transgenic animals. Many drugs - "small molecule" were removed from the market because they caused other diseases. There is a lack of understanding of what should be done to stop a disease, and why. Typically, one over- or under-expressed protein is targeted. However, considering that proteomic studies have shown that thousands of proteins are modified in the aging-associated diseases, targeting only one protein cannot stop a disease.

What is the upstream cause of the aging-associated diseases: is it gene or protein modification? If we believe that the diseases are caused by genetic errors, the system biology should be developed based on the upstream genetic changes. In contrast, if modifications of proteins by the small molecules are the upstream cause of the diseases, the modification by a small molecule in a primary cell culture or animal will be appropriate as a model of the disease.

The upstream work to prepare a system of biology should not be an accumulation of data by a shotgun approach, followed by computing, but be based on a clear hypothesis of the cause of the diseases in aging that is confirmed by results in vivo. The upstream cause of diseases should be established before system biology is constructed. The system biology of disease caused by protein modifications by the small molecule and a transgenic animal model that leads to similar symptoms of the disease yield data belonging to different systems. The data obtained in one system is not useful for another system.

\section{Protein-protein interactions: the same rule-the same system biology}

The system biology should explain protein-protein interactions as a consequence of gene changes, or the interactions between the proteins after their modification by the small molecules. The protein network (not genes) plays an executive role in physiology or diseases; a modification of proteins in aging by the small molecules, without any genetic changes, would lead to diseases. However, if an interconnection does not exist in the collected data, we cannot consider these data as "system biology"; we would have only an accumulation of data. The right system biology should provide proof of concept in vivo, for example, elimination of the modified proteins should eliminate the pathological system and provide a reprieve from pathology. Numerous failures in clinical studies of drugs developed in transgenic animal models indicate that transgenic animal models are not appropriate for the aging-associated diseases. The current approach to the aging-associated diseases prediction and biomarkers should be revised. We cannot create a genetic forecast for the diseases associated with aging and a genetic therapy for these diseases if protein modification is the upstream cause [7-9].

Small molecule model or genetic animal model of diseases, but not a mixture of both, should be used to find system biology responsible for disease

An impairment of the signaling protein network cause by a gene deletion could lead to severe diseases in early infancy. However, a healthy life for approximately 50 years or more cannot be possible if the numerous mutations found in the aging-associated diseases are upstream causes of the diseases associated with aging, such as retinal degeneration, cardiovascular disorders, or CNS degenerative diseases. On the contrary, the covalent modification of proteins by a small molecule, occurring in the course of a person's life, can be the upstream cause of diseases and result in genetic instability. The upstream modification of proteins leading to genome instability could explain the numerous mutations observed in cardiovascular disorders, Alzheimer's and Parkinson's diseases, retinal degeneration, and cancers. If the modifications of 
proteins cause the diseases in aging, a transgenic animal model cannot be used as the model of these diseases, and the healing of the diseases should occur by elimination of the modified proteins.

\section{Link between system biology and the old story of oxidative stress and diseases}

Of the thousands of molecules playing a role in the mammalian body, xanthurenic acid corresponds well to a model molecule to study protein-protein interactions. Xanthurenic acid is formed on the tryptophan degradation pathway by IDO [10]. IDO is induced by the oxidative stress in aging infections, cancer [11], and the presence of modified peptides such as 1-42 beta-amyloid [12]. Hundreds of publications demonstrated that the induction of IDO is associated with pathological conditions such as depression, multiple sclerosis, pathological synovial fluids, senile cataract, skin disorder and immunosuppression [13-18]. Xanthurenic acid is the end product, contrary to the intermediary molecules from tryptophan degradation, kynurenines or quinolinic acid [19]. The heterocyclic structure of the xanthurenic acid can be oxidized to a quinone structure, which results in a quinone radical $[\mathbf{2 0}, \mathbf{2 1}]$. Semiquinone radicals are able to modify the secondary amino group of amino acids covalently, leading to further polymerization between the proteins' regulatory sequences [22]. The regulatory sequences of proteins are intrinsically disordered (IDSeq) to ensure multiple interactions between the proteins $[\mathbf{2 3}, \mathbf{2 4}]$. Interactions between the proteins are impossible after stable modification of IDSeq by a small molecule, protein regulation is abolished, and this leads to cell pathology. The results showed that the deletion of 1 or 2 genes interrupts the signaling protein networks, i.e., calmodulin (Cam), and the Cam-binding sites responsible for the regulation of many genes [25-27]. The impaired protein signaling regulation of Cam, and PIP2/Cam-binding sites leads to failure of the system biology, making system physiology impossible. The modification of the signaling proteins is the upstream cause of the system biology failure that leads to the aging-associated diseases.

The systems biology in health and diseases have different protein-protein interactions regulated and non-regulated, respectively

Knockout animals (for 1, 2, or even 3 genes) are used as models for the aging-associated diseases. A knockout in a gene leads to severe pathology in the animal in a short time. An alternative system leading to cell pathology is a modification of proteins by the small molecules, leading to covalent interactions between proteins and a pathological network [25]. Any manipulation of the cells, which establishes new rules governing the interaction between the signaling proteins, leads to new system biology. If both systems are the same, the interaction of the signaling proteins in an aging mammalian cell and a knockout cell should demonstrate the same character. Our previous studies showed that the MEF cell line undergoes constitutive phosphorylation of Bad and a different MARCKS interaction with Cam [27]. The network of the signaling proteins Cam and the PIP2/Cam-binding sites was entirely different in transgenic cells from the network in same WT cells. Moreover, the knockout cells demonstrated entirely different regulation (or lack thereof) by the small molecules than the WT cells did. Therefore, knockout cells are not appropriate for the study of drug development for the aging-associated diseases, which are caused by protein modification by the small molecules and not by gene deletion.

\section{What a difference between system biology in health and disease?}

The systems biology responsible for health and disease are different due to the basic principle that protein-protein interactions, in health, are regulated. Regulation of the protein network is a condition sine qua non for tissue homeostasis. In disease, the interactions between proteins are impaired or wrong. Incorrect regulation of proteins could be caused by a genetic mutation or by modification of the proteins by a small molecule in an irreversible, covalent way. A genetic mutation will lead to the misfolding of proteins, but not their polymerization. Moreover, the misfolded proteins, produce because mutations, are eliminated by the mechanism of control of quality protein in cell [28]. However, modification of the regulatory sequences of proteins by the small molecules in a covalent manner abolishes cell homeostasis (aging, infection). The following scenarios could play out: accessibility for the interaction is blocked, or the interacting proteins polymerize together. Currently, there are no reasonable approaches to explain the aging-associated pathology. The trend for high-throughput analysis indicates that there is the rather simplistic belief that diseases develop by chance. Medical biology research became a science without a straightforward mathematical rule, and equations with many unknowns, that were impossible to resolve, have been published on the basis of their technical excellence.

The question of an upstream origin, i.e., whether the agingassociated diseases are determined genetically, or if they are an effect of protein modification by the small molecules throughout a person's life, is not resolved.

Studies on the aging-associated pathologies were conducted based on the first (genetic), or second (small molecules) hypotheses, or even both, of the diseases' development, but the image of the diseases became even blurrier.

The genetic hypothesis of the diseases' development became a dogma in the last 20 years. Studies that did not use transgenic animals were considered low quality, giving credence to the studies using genetic tools and casting in shadow the scientists who worked on cell metabolism and protein modification as an upstream cause of the diseases in aging. This mainstream trend did not explain the mechanism 
of the aging-associated diseases and did not allow a reversion of the aging-associated pathology.

The aging-associated diseases usually manifest when a person is approximately 50 years old or older. This strongly suggests that the diseases do not have an upstream genetic cause. The diseases in genetic animal models develop extremely quickly after a few days. A mutation/deletion leads to extremely early onset of a disease, i.e., in infancy. Many mutations have been found in all aging-associated diseases. Alternatively, the contrary should be proven. Then, the mutation(s) could be a consequence, and not a cause of the aging-associated disorders, or the mutations are harmful for physiology only in aging because of impairment of the regulation of the system biology keeping the cell homeostasis. Then, the cause of the diseases to target should be the aging associated modification of proteins.

\section{Small molecules and cell pathology}

The modifications of proteins by the small molecules were reported to be responsible for the aging-related pathologies. The facts observed in the aging-associated diseases are rather strong advocacy for this possibility. First, epidemiology studies demonstrated the diseases' incidence in tandem with small molecules in the environment in more than 20,000 publications. Such epidemiological studies indicated that small molecules such as cigarette smoke or dioxin $[29,30]$, pollution, phenoxyphenol [31], as well as emotional or physical stress led to diseases [32,33] Moreover, epidemiological studies have shown that infections during life account for the metabolic disorder in aging, and early mortality. Infections lead to protein modification by the metabolites from the oxidative degradation of tryptophan by IDO [17,34-43].

Changes in protein expression in the presence of a small molecule, without any mutation, were described in numerous papers. The presence of the small molecules in a tissue or cell culture for a prolonged period leads to the covalent, then irreversible binding of the molecules to the proteins. The addition of a small molecule to a cell culture changes gene expression; for example, the addition of statin to HUVEC lines and primary cells changed gene expression [44]. Most genes that were expressed by untreated HUVEC were also expressed by untreated EA.hy 926 cells. EA.hy 926 cells constitutively expressed a large number of additional genes, many of which were related to cell cycle control and apoptosis. Atorvastatin induced differential expression of 2-fold or more of 103 genes in HUVEC (10 up, 93 down) and 466 genes in EA.hy 926 cells (198 up, 268 down) [44]. Physical stress by rapid atrial depolarization by appendage pacing led to changes of the expression of 387 genes, and SDS-PAGE demonstrated the reprogramming of myosin regulatory light chain isoform composition, with a significant increase of its ventricular isoform (MLC-2V) [45]. Ventricular JARID2 regulates ANF, MLC2A, and MHCA transcription and contributes to re-expression of the fetal gene program in decompensated aortic stenosis.
JARID2 appears crucial in transcriptional regulation of fetal genes. It was concluded that the results might emerge as a diagnostic marker for left ventricular decompensation in aortic stenosis [46]. Cardiac dysfunction observed in the streptozotocin (STZ) rat was associated with modification by carbonyl adducts of MHC-alpha and MHC-beta [47]. In zebrafish, trilostane, a 3 beta-hydroxysteroid dehydrogenase inhibitor, altered the RNA expression of 65 genes involved in cellular proliferation, differentiation, migration, and apoptosis [48]. Zebrafish blastula-stage embryos were exposed for 6 days post-fertilization to nominal levels of 2 and $40 \mathrm{mg} / \mathrm{L}$ of protein kinase $\mathrm{C}$ inhibitor, PKC412. Changes in expression were observed among 259 and 511 altered transcripts at 2 and $40 \mathrm{mg} / \mathrm{L}$, respectively [49]. Continuous dopaminergic treatment is considered to prevent or delay the occurrence of dyskinesia in patients with PD. Rotigotine is a non-ergolinic $D(3)>D(2)>D(1)$ dopamine-receptor agonist for the treatment of PD using a transdermal delivery system, providing stable plasma levels. The expression of 15 genes in the substantia nigra and of 11 genes in the striatum was altered under pulsatile treatments, which induced dyskinetic motor response, but was unchanged under continuous rotigotine treatment that did not cause dyskinetic motor response [50]. In vivo, epinephrine-mediated regulation of gene expression in human skeletal muscle and cDNA element microarrays showed that 1206 and 474 genes were up- or down-regulated, respectively [50]. Cardiovascular gene expression profiles were studied in exposure of zebrafish to 2,3,7,8-tetrachlorodibenzo-pdioxin (TCDD), a widespread environmental contaminant. Gene expression profiles obtained for 3-day-old zebrafish after early embryonic exposure to either 0.5 or $5.0 \mathrm{nM}$ TCDD exhibited changes; 516 clones were significantly differentially expressed [51]. Circulating white blood cells are exposed to systemic environmental risk factors. They are directly involved in the low-grade chronic inflammation related to CVD, and can be used for the phenotyping of patients [52].

In some studies, animals with deleted genes were additionally treated with a small molecule, or the gene expression in a genetically modified animal was studied as a function of animal aging. STZ was used as a model of type I diabetes in transgenic mice that express green fluorescent protein under the control of an endothelial-specific promoter (Tie2-GFP), allowing rapid isolation of the aortic endothelium [53]. Shifts in gene expression patterns with aging were observed in normoxic and post-ischemic murine hearts. The results were interpreted as the age-associated up-regulation of transcripts involved in cell death, oxygen transport, and metabolism in normoxic hearts. It was concluded that the reduced tolerance with age may be related to modification of signaling (particularly WNT and TGF-beta), and shifts in expression of immediate early genes, important in the regulation of cell death/survival, angiogenesis, and cardiac remodeling [54]. Sirt-3 knockouts or a cell culture growing in the presence of xanthurenic acid exhibited impaired 
mitochondrial function [55]. Then, it is not clear, that Sirt3 plays an important role in mitochondrial dysfunction in mammalian aging or a modification of protein by small molecule. Only, reversibility of the pathology in vivo by targeting gene or protein modification could explain the upstream cause.

The examples above show that there are numerous changes in gene expression when only one gene is modified, as well as in the presence of a small molecule. Both approaches are used without any reasonable explanation of the approach chosen. The results yield an equation with many unknown quantities that is impossible to solve.

What should be targeted to stop the aging associated diseases: small molecules, proteins, or genes?

The results presented by Malina HZ [27] showed that proteinprotein interactions in a WT cell line are different from those in transgenic cell lines. Transgenic animals are not appropriate to create a system of biology leading to the diseases associated with aging. Every transgenic animal represents different systems of biology because the protein-protein interactions are different, unless the contrary is proven. Until then, system biology based on results from different knockout animals cannot assist in the creation of a system existing in vivo.

Therefore, we should first identify the upstream cause of diseases to establish a rational background for system biology of the diseases in aging. Upstream to all attempts to prepare system biology, which governs a disease in aging, researchers should establish if genes or protein modifications are the upstream cause of the diseases. The correct system biology is one that allows rescue from a disease in humans, and not only in transgenic animals.

The lack of understanding of the system leading to diseases has a big impact on drug development. In spite of thousands of publications on the issue, currently, the development of a mechanism of the diseases associated with aging is ignored and drug development has barely any reasonable background, leading to very toxic and inefficient treatment of the diseases. The small molecules for the drugs for the aging-associated diseases are chosen through high-throughput screening and tested on transgenic animals. Many small molecule drugs were removed from the market because they caused other diseases. There is hardly any understanding of what should be done to stop a disease and why. Usually, one over- or underexpressed protein is targeted. However, considering that proteomics studies have showed that thousands of proteins are modified in the aging-associated diseases, treatment of only one protein cannot stop a disease.

Drug should eliminate a cause of disease; then, what is the upstream cause of the aging associated diseases? Animal models and targets for therapy depend on the upstream cause of the disease. Current drug development benefits high-throughput screening of genes and proteins in the diseases to identify system biology, which could explain the diseases' development.

Genetically modified animals are often used for protein analysis. However, the system of biology constructed on a genetic basis would be not useful if the upstream cause of the aging-associated disorder is protein modification by the small molecules, leading to protein polymerization. Stably modified protein-protein interactions can lead to signaling for cell degeneration by pathological apoptosis [25]. The polymerized proteins cannot be eliminated in protein turnover by the ubiquitin system. Moreover, they cannot be eliminated by RNA therapy, or treatment with drugs such as small molecules, peptides, or proteins. However, if DNA mutation were an upstream cause of the disease, the protein would become misfolded without polymerization. Protein modification by chemicals will prevent the aggregation of proteins, and manipulation of gene expression could target the genetic disease.

The results presented previously [27] showed that virustransformed cells and knockout cells have different systems of biology with specific protein-protein interactions. The findings on the protein-protein interactions in the knockout cells, which represent new system biology, are true only for this system. They could be used only for the genetically determinate diseases, but not for the aging-associated diseases where the genetic origin is doubtful. The results showed that the Bid-/- and DKO cells had abolished interactions between the proteins essential for cell life, such as signaling proteins Cam, and Cam/phosphatidylinositol-binding sites. The systems of biology in the WT cells and the knockout cells are different. The small molecule reacts differently in the WT, Bid- $/-$, and DKO systems. The knockout models of the diseases could be used only if the protein-protein interaction presented were the same in the animal model and in patients with Parkinson's, Alzheimer's, or cardiovascular diseases. The genetic models for the diseases were based on the symptoms of the diseases. Similar symptoms do not mean that the causes of the diseases are similar, and a different cause means a different target for treatment. Moreover, in view of the impairment in the knockout cells' viability, it appears improbable that people with these gene impairments develop the diseases only in the second century of their lives.

\section{Conclusion}

\section{Targeting the aging associated diseases: treatment should target cause}

Proteins in cells are connected not one-to-one, but by multiple interactions in an interactive system with, at minimum, signaling proteins. Animal transgenic models of diseases have been used for 20 years for the drug development. The animals heal efficiently, but the patients do not. Now, we know why this is so; the systems of biology in aging humans and in knockout mice are different and react to the small molecules in different ways. Likewise, systems of biology containing 
modified proteins or deleted genes differ from one another; accordingly, they react with the small molecules differently. There is a necessity to understand the upstream cause of the development of the aging-associated diseases before data accumulation by a shotgun approach and computing are carried out. The model for drug development should correspond to the upstream cause of the diseases. Biology, as with every science, should be based on logic. It is time to change the approach to the healing of the aging-associated diseases and research on the system in diseases.

We now know why there is a difference between research findings and the results of actual practice: the systems of biology in aging humans and in knockout mice are different and react to the small molecules in different ways. The small molecule or gene knockout lead to different systems biology and the data accumulation from both systems together are not appropriated to build the system biology. In the system biology, (according to system definition in general) data should be interactive. Accumulation of data for a system should be based on the upstream understanding what is the difference between health and disease. System biology in diseases is different from the system biology in health. System biology of the genetic disease or the disease caused by the protein modification is different. Upstream to the data accumulation to build a system, we should know what we look for and know a base of the system, or follow strictly a hypothesis, to say if it is right or wrong. The reversibility of the pathology by a proof of concept in vivo will confirm that the system is appropriated for a disease or not. The goal of biochemical research is not a data accumulation by shotgun, but a rational approach for the diseases therapy.

\section{Competing financial interest}

Malina HZ patents

Publication history

Received: 30-Apr-2012 Revised: 08-June-2012

Accepted: 24-July-2012 Published: 28-July-2012

\section{References}

1. Lidington EA, Moyes DL, McCormack AM, Rose ML: A comparison of primary endothelial cells and endothelial cell lines for studies of immune interactions. Transpl Immunol 1999; 7;(4.);239-46. | Article | PubMed

2. Yokomuro S, Tsuji H, Lunz JG, 3rd, Sakamoto T, Ezure T, Murase N, et al.: Growth control of human biliary epithelial cells by interleukin 6 , hepatocyte growth factor, transforming growth factor beta1, and activin A: comparison of a cholangiocarcinoma cell line with primary cultures of non-neoplastic biliary epithelial cells. Hepatology 2000; 32;(1.);26-35. I Article I PubMed

3. Audet M, Lagace M, Silversides DW, Bouvier M: Protein-protein interactions monitored in cells from transgenic mice using bioluminescence resonance energy transfer. FASEB J 2010; 24;(8.);2829-38. | Article | PubMed

4. Pan C, Kumar C, Bohl S, Klingmueller U, Mann M: Comparative proteomic phenotyping of cell lines and primary cells to assess preservation of cell type-specific functions. Mol Cell Proteomics 2009; 8;(3.);443-50. | Article | PubMed Abstract | PubMed Full Text

5. Ivanov R, Hol S, Aarts TI, Hagenbeek A, Ebeling SB: T cell receptor- transgenic primary $\mathrm{T}$ cells as a tool for discovery of leukaemiaassociated antigens. Clin Exp Immunol 2006; 143;(1.);78-84. | Article | PubMed Abstract | PubMed Full Text

6. Hammoud L, Burger DE, Lu X, Feng Q: Tissue inhibitor of metalloproteinase-3 inhibits neonatal mouse cardiomyocyte proliferation via EGFR/JNK/SP-1 signaling. Am J Physiol Cell Physiol 2009; 296; (4.);C735-45. | Article | PubMed

7. Allegrucci C, Rushton MD, Dixon JE, Sottile V, Shah M, Kumari R, et al.: Epigenetic reprogramming of breast cancer cells with oocyte extracts. Mol Cancer 2011; 10;(1.);7. I Article I PubMed Abstract I PubMed Full $\underline{\text { Text }}$

8. Hirsch HA, Iliopoulos D, Joshi A, Zhang Y, Jaeger SA, Bulyk M, et al.: A transcriptional signature and common gene networks link cancer with lipid metabolism and diverse human diseases. Cancer Cell 2010; 17;(4.);348-61. I Article | PubMed Abstract | PubMed Full Text

9. Iliopoulos D, Hirsch HA, Struhl K: An epigenetic switch involving NF-kappaB, Lin28, Let-7 MicroRNA, and IL6 links inflammation to cell transformation. Cell 2009; 139;(4.);693-706. I Article I PubMed Abstract | PubMed Full Text

10. Brown RR, Ozaki Y, Datta SP, Borden EC, Sondel PM, Malone DG: Implications of interferon-induced tryptophan catabolism in cancer, auto-immune diseases and AIDS. Adv Exp Med Biol 1991; 294;(425-35. | Article | PubMed

11. Malina HZ, Martin XD: Indoleamine 2,3-dioxygenase: antioxidant enzyme in the human eye. Graefes Arch Clin Exp Ophthalmol 1996; 234;(7.);457-62. | Article | PubMed

12. Guillemin GJ, Smythe GA, Veas LA, Takikawa O, Brew BJ: A beta 1-42 induces production of quinolinic acid by human macrophages and microglia. Neuroreport 2003; 14;(18.);2311-5. I Article I PubMed

13. Dobos $\mathrm{N}$, de Vries EF, Kema IP, Patas K, Prins M, Nijholt IM, et al.: The role of indoleamine 2,3-dioxygenase in a mouse model of neuroinflammation-induced depression. J Alzheimers Dis 2012; 28;(4.);905-15. I Article I PubMed

14. Sakurai K, Zou JP, Tschetter JR, Ward JM, Shearer GM: Effect of indoleamine 2,3-dioxygenase on induction of experimental autoimmune encephalomyelitis. J Neuroimmunol 2002; 129;(1-2.);18696. I Article I PubMed

15. Bertazzo A, Punzi L, Bertazzolo N, Pianon M, Pozzuoli A, Costa CV, et al.: Tryptophan catabolism in synovial fluid of various arthropathies and its relationship with inflammatory cytokines. Adv Exp Med Biol 1999; 467;(565-70. I PubMed

16. Malina HZ, Martin XD: Deamination of 3-hydroxykynurenine in bovine lenses: a possible mechanism of cataract formation in general. Graefes Arch Clin Exp Ophthalmol 1995; 233;(1.);38-44. I Article I PubMed

17. von Bubnoff D, Scheler M, Wilms H, Wenzel J, von Bubnoff N, Hacker $\mathrm{G}$, et al.: Indoleamine 2,3-dioxygenase-expressing myeloid dendritic cells and macrophages in infectious and noninfectious cutaneous granulomas. J Am Acad Dermatol 2011; 65;(4.);819-32. | Article | PubMed

18. Suzuki Y, Suda T, Furuhashi K, Suzuki M, Fujie M, Hahimoto D, et al.: Increased serum kynurenine/tryptophan ratio correlates with disease progression in lung cancer. Lung Cancer 2010; 67;(3.);361-5. I Article | PubMed

19. Opitz CA, Litzenburger UM, Sahm F, Ott M, Tritschler I, Trump S, et al:: An endogenous tumour-promoting ligand of the human aryl hydrocarbon receptor. Nature 2011; 478;(7368.);197-203. I Article I PubMed

20. Malina HZ, Martin XD: 3-hydroxykynurenine transamination leads to the formation of the fluorescent substances in human lenses. Eur J Ophthalmol 1996; 6;(3.);250-6. I PubMed

21. Bolton JL, Trush MA, Penning TM, Dryhurst G, Monks TJ: Role of quinones in toxicology. Chem Res Toxicol 2000; 13;(3.);135-60. | Article I PubMed

22. Malina $\mathrm{HZ}$ : Xanthurenic acid provokes formation of unfolded proteins in endoplasmic reticulum of the lens epithelial cells. Biochem Biophys Res Commun 1999; 265;(2.);600-5. I Article I PubMed

23. Dyson HJ, Wright PE: Intrinsically unstructured proteins and their 
functions. Nat Rev Mol Cell Biol 2005; 6;(3.);197-208. | Article

24. Ferreon JC, Lee CW, Arai M, Martinez-Yamout MA, Dyson HJ, Wright $\mathrm{PE}$ : Cooperative regulation of $\mathrm{p} 53$ by modulation of ternary complex formation with CBP/p300 and HDM2. Proc Natl Acad Sci U S A 2009; 106;(16.);6591-6. | Article | PubMed Abstract | PubMed Full Text

25. Malina HZ, Richter C, MehI M, Hess OM: Pathological apoptosis by xanthurenic acid, a tryptophan metabolite: activation of cell caspases but not cytoskeleton breakdown. BMC Physiol 2001; 1;(7. | Article | PubMed Abstract | PubMed Full Text

26. Malina $\mathrm{HZ}$, Frueh $\mathrm{BE}$ : Abnormal signalling of 14-3-3 proteins in cells with accumulated xanthurenic acid. Biochem Biophys Res Commun 2003; 310;(2.);646-50. I Article | PubMed

27. Malina HZ: System in biology leading to cell pathology: stable proteinprotein interactions after covalent modifications by small molecules or in transgenic cells. J Biomed Sci 2011; 18;(7. | Article | PubMed Abstract | PubMed Full Text

28. Goldberg AL: Protein degradation and protection against misfolded or damaged proteins. Nature 2003; 426;(6968.);895-9. | Article | PubMed

29. McCall BJ, Neill AS, Young MM: Risk factors for invasive meningococcal disease in southern Queensland, 2000-2001. Intern Med J 2004; 34;(8.);464-8. | Article | PubMed

30. Marshall NB, Kerkvliet NI: Dioxin and immune regulation: emerging role of aryl hydrocarbon receptor in the generation of regulatory $\mathrm{T}$ cells. Ann N Y Acad Sci 2010; 1183;(25-37. | Article | PubMed

31. Mazzone $P$, Tierney $W$, Hossain $M$, Puvenna V, Janigro $D$, Cucullo L: Pathophysiological impact of cigarette smoke exposure on the cerebrovascular system with a focus on the blood-brain barrier: expanding the awareness of smoking toxicity in an underappreciated area. Int J Environ Res Public Health 2010; 7;(12.);4111-26. | Article | PubMed Abstract I PubMed Full Text

32. Soufer $\mathrm{R}$, Jain $\mathrm{H}$, Yoon AJ: Heart-brain interactions in mental stressinduced myocardial ischemia. Curr Cardiol Rep 2009; 11;(2.);133-40. I Article | PubMed

33. Stojanovich L: Stress and autoimmunity. Autoimmun Rev 2010; 9;(5.);A271-6. | Article | PubMed

34. Fuchs D, Moller AA, Reibnegger G, Stockle E, Werner ER, Wachter $\mathrm{H}$ : Decreased serum tryptophan in patients with HIV-1 infection correlates with increased serum neopterin and with neurologic/ psychiatric symptoms. J Acquir Immune Defic Syndr 1990; 3;(9.);873-6. I PubMed

35. Beatty WL, Belanger TA, Desai AA, Morrison RP, Byrne GI: Tryptophan depletion as a mechanism of gamma interferon-mediated chlamydial persistence. Infect Immun 1994; 62;(9.);3705-11. | Article | PubMed Abstract | PubMed Full Text

36. Vincendeau P, Lesthelle S, Bertazzo A, Okomo-Assoumou MC, Allegri G, Costa CV: Importance of L-tryptophan metabolism in trypanosomiasis. Adv Exp Med Biol 1999; 467;(525-31. I PubMed

37. Potula R, Poluektova L, Knipe B, Chrastil J, Heilman D, Dou H, et al.: Inhibition of indoleamine 2,3-dioxygenase (IDO) enhances elimination of virus-infected macrophages in an animal model of HIV-1 encephalitis. Blood 2005; 106;(7.);2382-90. | Article | PubMed Abstract I PubMed Full Text

38. Montagnoli C, Bozza S, Gaziano R, Zelante T, Bonifazi P, Moretti S, et al.: Immunity and tolerance to Aspergillus fumigatus. Novartis Found Symp 2006; 279;(66-77; discussion -9, 216-9. I Article | PubMed

39. Boasso A, Herbeuval JP, Hardy AW, Anderson SA, Dolan MJ, Fuchs D, et al.: HIV inhibits $\mathrm{CD} 4+\mathrm{T}$-cell proliferation by inducing indoleamine 2,3-dioxygenase in plasmacytoid dendritic cells. Blood 2007; 109;(8.);3351-9. | Article | PubMed Abstract | PubMed Full Text

40. Larrea E, Riezu-Boj II, Gil-Guerrero L, Casares N, Aldabe R, Sarobe P, et al.: Upregulation of indoleamine 2,3-dioxygenase in hepatitis $C$ virus infection. J Virol 2007; 81;(7.);3662-6. | Article | PubMed Abstract | PubMed Full Text

41. Schroecksnadel K, Zangerle R, Bellmann-Weiler R, Garimorth K, Weiss G, Fuchs $D$ : Indoleamine-2, 3-dioxygenase and other interferon-gammamediated pathways in patients with human immunodeficiency virus infection. Curr Drug Metab 2007; 8;(3.);225-36. | Article | PubMed

42. Malleret B, Maneglier B, Karlsson I, Lebon P, Nascimbeni M, Perie $L$, et al.: Primary infection with simian immunodeficiency virus: plasmacytoid dendritic cell homing to lymph nodes, type I interferon, and immune suppression. Blood 2008; 112;(12.);4598-608. | Article | PubMed

43. Boasso A: Wounding the immune system with its own blade: HIVinduced tryptophan catabolism and pathogenesis. Curr Med Chem 2011; 18;(15.);2247-56. | Article | PubMed

44. Boerma M, Burton GR, Wang J, Fink LM, McGehee RE, Jr., Hauer-Jensen $M$ : Comparative expression profiling in primary and immortalized endothelial cells: changes in gene expression in response to hydroxy methylglutaryl-coenzyme A reductase inhibition. Blood Coagul Fibrinolysis 2006; 17;(3.);173-80. | Article | PubMed

45. Lai LP, Lin JL, Lin CS, Yeh HM, Tsay YG, Lee CF, et al.: Functional genomic study on atrial fibrillation using cDNA microarray and two-dimensional protein electrophoresis techniques and identification of the myosin regulatory light chain isoform reprogramming in atrial fibrillation. $J$ Cardiovasc Electrophysiol 2004; 15;(2.);214-2. I Article I PubMed

46. Bovill E, Westaby S, Reji S, Sayeed R, Crisp A, Shaw T: Induction by left ventricular overload and left ventricular failure of the human Jumonji gene (JARID2) encoding a protein that regulates transcription and reexpression of a protective fetal program. J Thorac Cardiovasc Surg 2008; 136;(3.);709-16. | Article | PubMed

47. Shao CH, Rozanski GJ, Nagai R, Stockdale FE, Patel KP, Wang M, et al.: Carbonylation of myosin heavy chains in rat heart during diabetes. Biochem Pharmacol 2010; 80;(2.);205-17. | Article | PubMed Abstract | PubMed Full Text

48. Small CM, Carney GE, Mo Q, Vannucci M, Jones AG: A microarray analysis of sex- and gonad-biased gene expression in the zebrafish: evidence for masculinization of the transcriptome. BMC Genomics 2009; 10; (579. | Article | PubMed Abstract | PubMed Full Text

49. Oggier DM, Weisbrod CJ, Stoller AM, Zenker AK, Fent K: Effects of diazepam on gene expression and link to physiological effects in different life stages in zebrafish Danio rerio. Environ Sci Technol 2010; 44;(19.);7685-91. I Article | PubMed

50. Grunblatt E, Schmidt WJ, Scheller DK, Riederer P, Gerlach M: Transcriptional alterations under continuous or pulsatile dopaminergic treatment in dyskinetic rats. J Neural Transm 2011; 118;(12.);1717-25. | Article | PubMed

51. Handley-Goldstone HM, Grow MW, Stegeman JJ: Cardiovascular gene expression profiles of dioxin exposure in zebrafish embryos. Toxicol Sci 2005; 85;(1.);683-93. I Article I PubMed

52. Ardigo D, Gaillard CA, Braam B: Application of leukocyte transcriptomes to assess systemic consequences of risk factors for cardiovascular disease. Clin Chem Lab Med 2007; 45;(9.);1109-20. I Article I PubMed

53. Maresh JG, Shohet RV: In vivo endothelial gene regulation in diabetes. Cardiovasc Diabetol 2008; 7;(8. | Article | PubMed Abstract | PubMed Full Text

54. Ashton KJ, Willems L, Holmgren K, Ferreira L, Headrick JP: Ageassociated shifts in cardiac gene transcription and transcriptional responses to ischemic stress. Exp Gerontol 2006; 41;(2.);189-204. I Article I PubMed

55. Kim HS, Patel K, Muldoon-Jacobs K, Bisht KS, Aykin-Burns N, Pennington JD, et al.: SIRT3 is a mitochondria-localized tumor suppressor required for maintenance of mitochondrial integrity and metabolism during stress. Cancer Cell 2010; 17;(1.);41-52. | Article | PubMed

Citation:

Malina HZ: A Rational Basis for System Biology in the Aging-Associated Diseases: Are Genes or Protein Modifications the Upstream Cause? journal of Molecular Engineering and Systems Biology 2012, 1:3. http://dx.doi.org/10.7243/2050-1412-1-3 